\title{
Managing the almond and stone fruit replant disease complex with less soil fumigant
}

\author{
by Greg T. Browne, Bruce D. Lampinen, \\ Brent A. Holtz, David A. Doll, Shrinivasa K. \\ Upadhyaya, Leigh S. Schmidt, Ravindra G. Bhat, \\ Vasu Udompetaikul, Robert W. Coates, Bradley \\ D. Hanson, Karen M. Klonsky, Suduan Gao, \\ Dong Wang, Matt Gillis, James S. Gerik and \\ R. Scott Johnson
}

\section{As much as one-third of California's almond and stone fruit acreage is in-} fested with potentially debilitating plant parasitic nematodes, and even more of the land is impacted by Prunus replant disease (PRD), a poorly understood soilborne disease complex that suppresses early growth and cumulative yield in replanted almond and peach orchards. Preplant soil fumigation has controlled these key replant problems, but the traditional fumigant of choice, methyl bromide, has been phased out, and other soil fumigants are increasingly regulated and expensive. We tested fumigant and nonfumigant alternatives to methyl bromide in multiple-year replant trials. Costs and benefits were evaluated for alternative fumigants applied by shanks in conventional strip and full-coverage treatments and applied by shanks or drip in novel spot treatments that targeted tree planting sites. Short-term sudangrass rotation and prudent rootstock selection were examined as nonfumigant approaches to managing PRD. Trial results indicated that integrations of the treatments may acceptably control PRD with relatively little soil fumigant.

\footnotetext{
pproximately 1 million acres of California's best agricultural land are devoted to production of almonds and stone fruits (USDA 2011), and sustained high production from this land requires that the orchards be replanted every 15 to 25 years, depending on the production
}

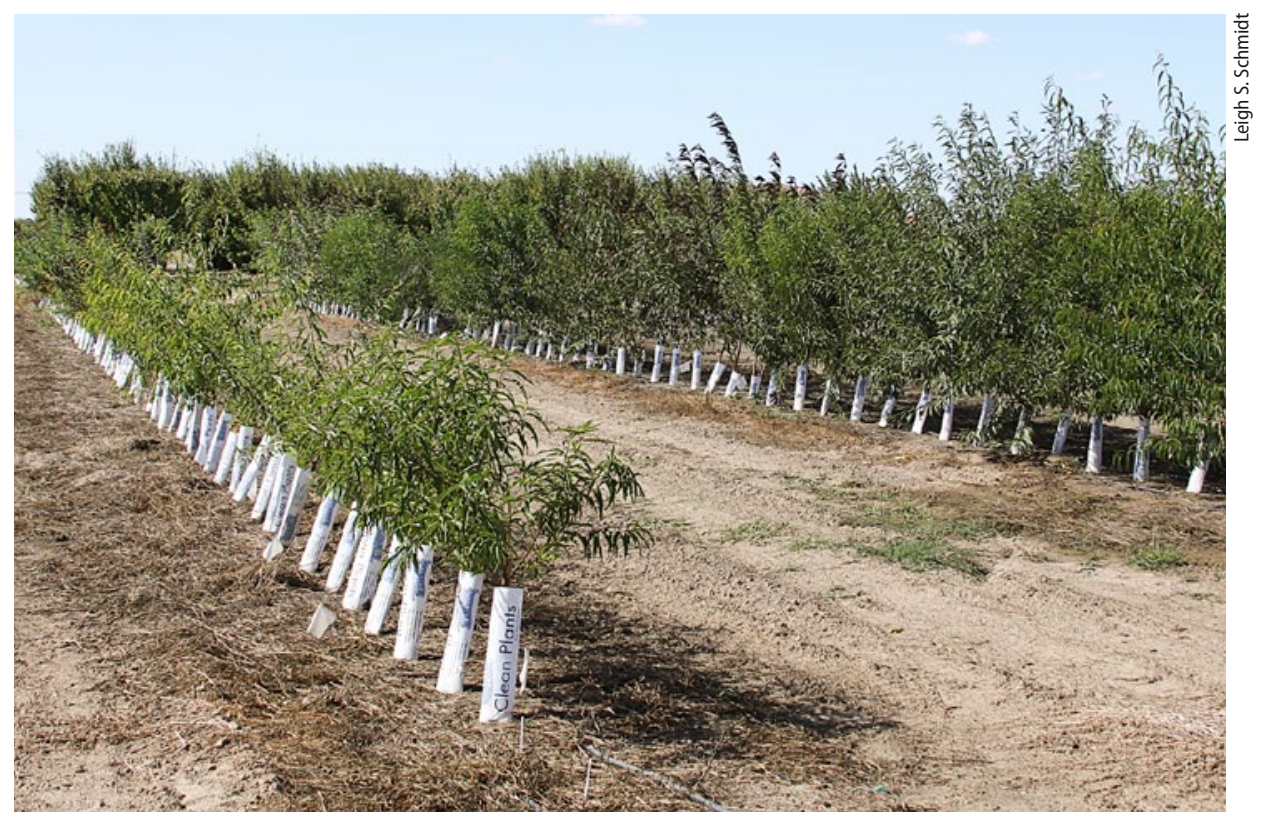

Rootstocks for almonds and stone fruits were tested for their resistance to the Prunus replant disease complex near Parlier, CA. Shown are a plot of PRD-affected rootstocks in nonfumigated replant soil, left, and a plot of relatively healthy rootstocks grown in soil preplant fumigated with 1,3-D:Pic 63:65 (Telone C35), right.

system. Research has documented myriad problems that can suppress growth and productivity in such replanted orchards (Bent et al. 2009; Browne et al. 2006; Larsen 1995; McKenry 1996, 1999; Westerdahl and McKenry 2002). Abiotic soil factors related to previous crop production, such as compaction, salinity, suboptimal $\mathrm{pH}$, nutritional imbalances and herbicide residues, can compromise the performance of replanted orchards, but many of these problems can be avoided or remedied without great difficulty or expense.

Biotic replant problems, including plant parasitic nematodes and Prunus replant disease (PRD), can pose more of a challenge. Plant parasitic nematodes infest as much as one-third of California's almond and stone fruit acreage (McKenry and Kretsch 1987) and have the potential to compromise all phases of an orchard's productive life by inflicting root damage. Several rootstocks for almonds and stone fruit have shown genetic resistance to root knot nematodes, but little resistance has been demonstrated against the other two major nematode pests affecting these crops, the ring nematode and the root lesion nematode (McKenry 2007). PRD, which is much more widespread than nematode damage on almonds and stone fruits, is a poorly understood soilborne disease complex that suppresses early growth and cumulative yield in replanted almond and peach orchards (Bent et al. 2009; Browne et al. 2006). It afflicts successive generations of almonds and stone fruit planted at the same location and is associated with poor health of the trees' fine roots and incidence of several plantparasitic fungi and oomycetes. The severity of the disease varies greatly among orchards, but it is observed most commonly on loam, sandy loam, and sand soil textures in California. PRD can occur on its own or in combination with other replant problems.

Preplant soil fumigation has been an effective means of control for biological replant problems, but fumigant usage today is being challenged on several fronts, including the phase-out of methyl bromide (US EPA 2012), township caps on the use of the fumigant 1,3-dichloropropene (1,3-D) (Carpenter et al. 2001), volatile organic compound regulations under the

Online: http://californiaagriculture.ucanr.edu/ landingpage.cfm?article=ca.v067n03p128\&fulltext=yes doi: 10.3733/ca.v067n03p128 
U.S. Clean Air Act (Cal-DPR 2012), and increasingly restrictive buffer zones (see pages 122-127 for explanation and more details on each of these topics). Due to required buffer zones (to protect bystanders from unintended exposure), many fields have large areas that cannot be treated using conventional fumigation.

\section{Reducing dependence on fumigation}

Over the long term, breeding of rootstocks that broadly resist or tolerate soilborne pathogens and development of cultural practices that effectively remediate replant problems may remove dependence on soil fumigation. In this article we report on the effectiveness of options currently available for control of the most widespread almond and stone fruit replant problem, PRD. We examine the potential contributions of optimized soil fumigation methods, crop rotation and rootstock selection to the integrated management of PRD and reduced fumigant use.

\section{Almond replant trials}

As part of our research, we established two almond replant trials in Madera County focused on fumigant-based options for control of PRD. The trials were designed to help optimize soil fumigation practices by identifying fumigant formulations that are particularly effective for control of the disease complex and by determining the effectiveness of different fumigant rates and novel fumigant delivery methods. Regarding the latter emphasis, GPS-based software and hardware systems were developed recently to deliver spot fumigation treatments by tractor to tree planting sites (Coates et al. 2007; Udompetaikul et al. in press). The new spot treatment system was designed for planning, mapping and treating all tree sites in a replacement orchard and is considered to be much safer and faster than spot fumigation treatments applied with a hand-held probe. Spot treatment can reduce the amount of fumigant required to treat an orchard acre by $50 \%$ to $90 \%$, but evaluations of the GPS-controlled tractor application system were needed.

Two orchards in California, one near Firebaugh and the other near Madera, were selected for replanting experiments. The Firebaugh trial included soils of Dinuba fine sandy loam, El Peco fine sandy loam and Fresno fine sandy loam,

\section{Optimized soil fumigation, crop rotation and rootstock selection are valuable components for integrated management of PRD.}

whereas the Madera trial included El Peco, Fresno, and Lewis sandy loams and Tujunga loamy sand. Lands for the Firebaugh and Madera replant trials were cleared of old almond orchards grown on 'Nemaguard' rootstock in the summers of 2006 and 2007, respectively, using conventional practices. After removal, the old trees were chipped (the removed tree residue was ground up by a tub grinder and hauled away for energy generation or other uses). To reduce soil compaction, the cleared lands were ripped to a depth of 5 to 6 feet and then smoothed. In preparation for soil fumigation, the lands were then sprinkler irrigated with about 1.5 inches of water to reduce the potential for fumigant emissions to escape into the atmosphere.

Fumigants were applied to the soil in October 2006 for the Firebaugh trial and October 2007 for the Madera trial. The fumigant formulations were:

- methyl bromide (MB), 98\%; chloropicrin (Pic), 2\%, as a warning agent (MBC Concentrate, TriCal Inc.)

- 1,3-D, 98\% (Telone II)

- chloropicrin (Pic), 99\% (Tri-Clor)
- mixtures of 1,3-D:Pic, including 63:35 (Telone C35) and 39:60, (Pic-Clor 60)

- iodomethane (IM):Pic 50:50 (Midas)

In each orchard, all preplant soil fumigation treatments were applied by TriCal Inc. (Hollister, CA) to plots that would accommodate a width of three tree rows (66 feet) and a length of 10 tree spaces (140 to 170 feet). The MB treatments were applied with a conventional MB rig (TriCal Inc.), and the system injected fumigant at soil depths of 18 to 20 inches through two shanks spaced 60 inches apart; one pass was made for each tree row, effectively treating a 10-foot-wide strip. The other fumigant treatments were applied with a Telone rig (TriCal Inc.), which also injected fumigants at soil depths of 18 to 20 inches, but through three or five shanks (depending on the treatment). The shanks were spaced 20 inches apart and tipped with horizontal "wing" attwo points 8 inches apart, one behind each wing tip. The rig was used to apply three types of treatments: single-pass strip treatments, in which fumigant was tachments. Fumigant was released from

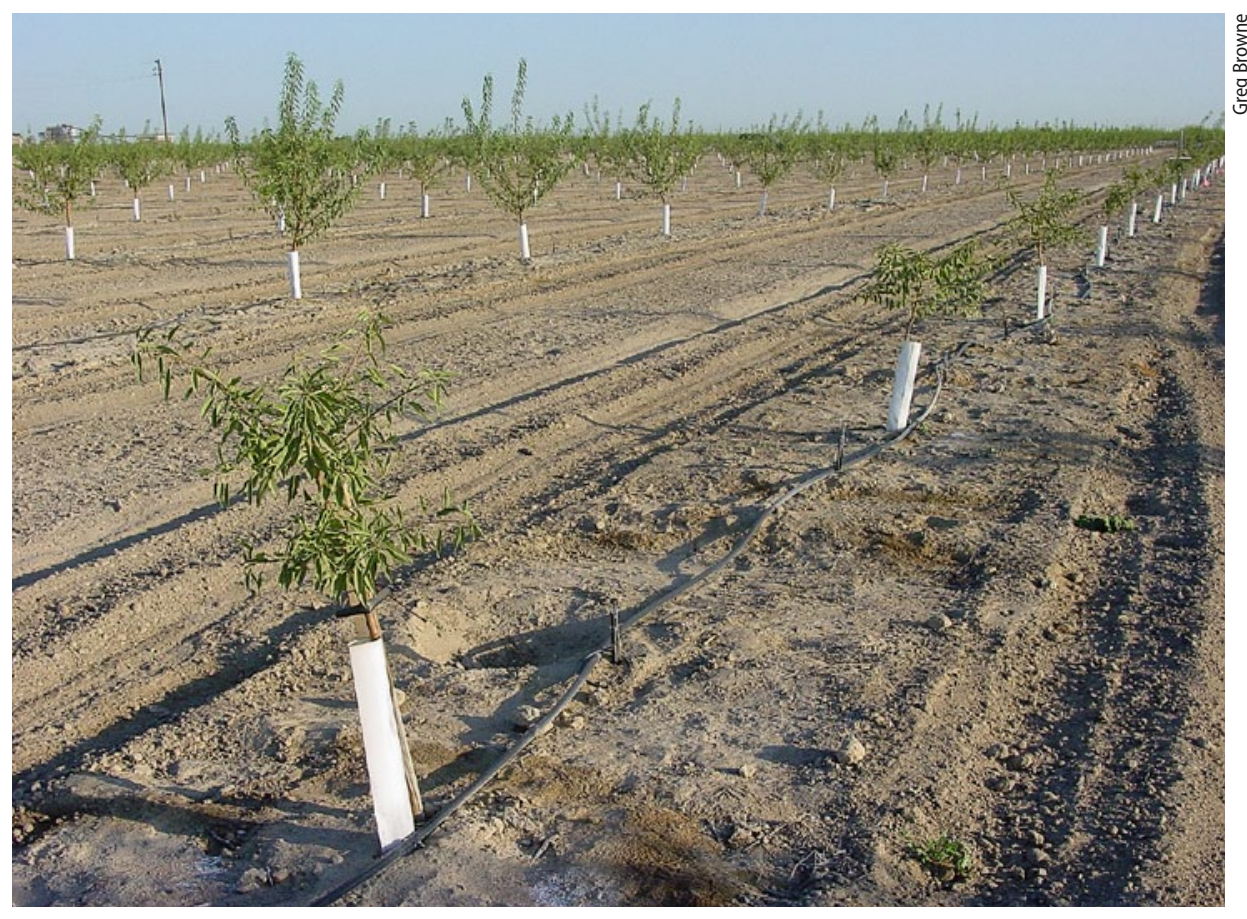

First-year impact of Prunus replant disease at the Firebaugh replant trial; stunted trees in the foreground row were planted in plot of nonfumigated replant soil, while trees in the background rows were planted in preplant fumigated soil. 
applied only to 8.3-foot-wide strips centered over future tree rows; full-coverage treatments, in which the entire area of a replicate plot received fumigant; and spot treatments, in which either 8.3-foot-wide by 8 -foot-long (Firebaugh trial) or 5-footwide by 7-foot-long (Madera trial) rectangular areas centered over future tree sites were treated.

The spot treatments were administered via a Telone rig retrofitted with GPSbased software and hardware to rapidly turn shank injections off and on as the tractor traveled down the future tree rows with the shanks remaining in the soil (Coates et al. 2007; Upadhyaya et al. 2009; Udompetaikul et al. in press). Before the spot applications began, the software was used to create a virtual map of each orchard's future tree sites according to desired row and tree spacings and planting patterns (rectangular and diamond planting patterns were used in the Firebaugh and Madera trials, respectively), and the desired width and length of the zones to be fumigated around each mapped tree planting site were selected.

The control plots were ripped with Telone rig shanks but received no fumigant. Each treatment was applied to several replicate plots (six at Firebaugh and five at Madera). The plots were randomized in a complete block design.

The Firebaugh trial was replanted in January 2007, and the Madera trial in January 2008. In each replicate plot, a center row was replanted to 'Nonpareil' almond and the two adjacent rows were

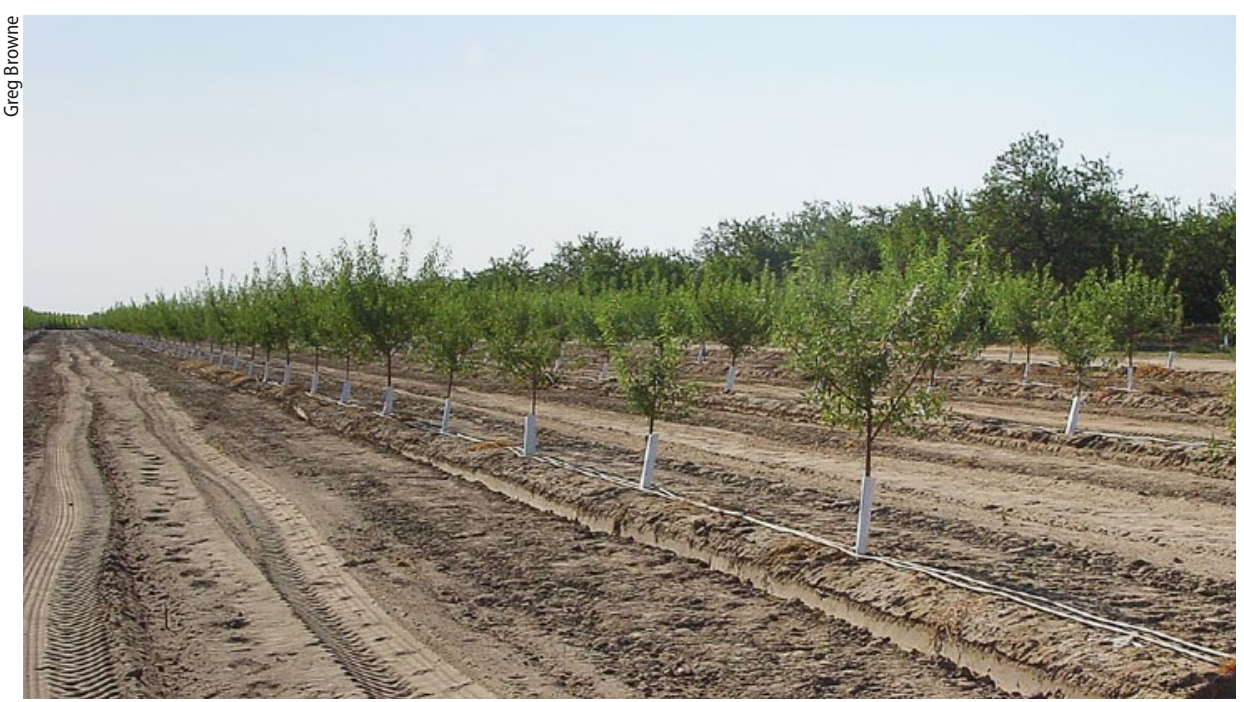

First-year impact of Prunus replant disease at the Madera replant trial; stunted trees in the foreground were planted in plot of nonfumigated replant soil, while larger trees in the background of the same row were in plot of preplant fumigated soil. cross-pollination. In all cases, the rootstock for 'Nonpareil' was 'Nemaguard' peach. Efficacy of the treatments was assessed according to the percentage of incident photosynthetically active radiation (PAR) intercepted by the 'Nonpareil' tree canopies in midsummer and nut yields collected starting in the third growing season and annually thereafter. To measure the PAR interception, we used a new mobile platform that provides a good estimate of the yield potential of tree canopies (Lampinen et al. 2012).

\section{Almond replant trial results}

In both the Firebaugh and Madera trials, most of the preplant soil fumigation treatments showed enhanced canopy growth through the first and second yield years (the third and fourth growing seasons after planting, respectively) when compared to the nonfumigated control (table 1; $P=0.002$ to $<0.0001$ for effect fumigant treatment).

At Firebaugh, compared to the control, preplant strip treatments with $\mathrm{MB}$ and 1,3-D boosted PAR interception by $20 \%$ and $39 \%$, respectively, in yield year 1 (table 1). Thereafter, these fumigation treatments had little effect on PAR interception. Other fumigant treatments at Firebaugh, including Pic and combinations of Pic with 1,3-D or IM, were generally more effective than the MB and 1,3-D treatments, boosting mean PAR interception by $56 \%$ to $97 \%$ in yield year 1 and $11 \%$ to $22 \%$ in yield year 2 compared to the replanted to other varieties selected for 
still increased net crop revenues, but the returns were again negative for the $\mathrm{MB}$ treatment and relatively low for the 1,3-D:Pic 63:35 full-coverage treatment. We intend to continue annual PAR and yield measurements in the Madera and Firebaugh trials. Yields have not converged among the treatments, suggesting that their economic value will continue to sort out over time.

Soil sampling from all replicate plots of the control, MB strip and 1,3-D:Pic 63:35 broadcast treatments detected negligible to small nematode populations in 2009 and 2012. Specifically, in 2009 at Firebaugh, we detected one ring nematode per half pint (250 milliliters) of soil from one MB-treated plot, and no lesion, ring or root knot nematodes from other plots; at Madera, there were three lesion nematodes per half pint (250 milliliters) of

TABLE 1. Results summary, almond replant trials in Madera County

\begin{tabular}{|c|c|c|c|c|c|c|c|c|c|c|c|c|c|c|c|}
\hline \multirow[b]{2}{*}{ Trial } & \multirow[b]{2}{*}{ Fumigant* } & \multirow[b]{2}{*}{ Coverage } & \multirow{2}{*}{\multicolumn{2}{|c|}{ Fumigant rate }} & \multirow[b]{2}{*}{$\begin{array}{c}\text { Cost of } \\
\text { treatment }\end{array}$} & \multicolumn{3}{|c|}{$\begin{array}{l}\text { Photosynthetically active } \\
\text { radiation (PAR) absorbed }\end{array}$} & \multicolumn{3}{|c|}{ Cumulative yield } & \multicolumn{2}{|c|}{$\begin{array}{l}\text { Cumulative } \\
\text { net revenue } \\
\text { gaint }\end{array}$} & \multicolumn{2}{|c|}{$\begin{array}{l}\text { Fumigant } \\
\text { efficiency }\end{array}$} \\
\hline & & & & & & $\begin{array}{c}\text { Yield } \\
\text { year } 1\end{array}$ & $\begin{array}{l}\text { Yield } \\
\text { year } 2\end{array}$ & $\begin{array}{l}\text { Yield } \\
\text { year } 3\end{array}$ & $\begin{array}{l}\text { Yield } \\
\text { year } 1\end{array}$ & $\begin{array}{l}\text { Yield } \\
\text { year } 2\end{array}$ & $\begin{array}{l}\text { Yield } \\
\text { year } 3\end{array}$ & $\begin{array}{l}\text { Yield } \\
\text { year } 2\end{array}$ & $\begin{array}{l}\text { Yield } \\
\text { year } 3\end{array}$ & $\begin{array}{l}\text { Yield } \\
\text { year } 2\end{array}$ & $\begin{array}{l}\text { Yield } \\
\text { year } 3\end{array}$ \\
\hline & & & $\begin{array}{l}\text { Ib/treated } \\
\text { acre }\end{array}$ & $\begin{array}{l}\text { lb/orchard } \\
\text { acre }\end{array}$ & $\$$ /acre & . & $\%$ & $\cdots \cdots$ & $\cdots \cdots / b k$ & kernels/ac & cre....... & $\cdots \$ / a$ & acre.... & $\begin{array}{l}\text { net } \$ g \\
\text { lb fumi }\end{array}$ & $\begin{array}{l}\text { gain/ } \\
\text { nigant }\end{array}$ \\
\hline \multirow[t]{15}{*}{ Firebaugh } & Control & None & 0 & 0 & 0 & 16 & 46 & 59 & 161 & 856 & 3,024 & 0 & 0 & - & - \\
\hline & $\mathrm{MB}$ & Strip (45\%) & 400 & 180 & 1,962 & 19 & 46 & 54 & 455 & 1,277 & 3,366 & $(1,120)$ & $(1,279)$ & $(6.22)$ & (7.10) \\
\hline & $1,3-D$ & Strip (38\%) & 340 & 129 & 393 & 22 & 50 & 58 & 547 & 1,517 & 3,997 & 929 & 1,552 & 7.19 & 12.01 \\
\hline & Pic & Strip (38\%) & 400 & 152 & 871 & 29 & 54 & 61 & 932 & 2,088 & 4,676 & 1,593 & 2,433 & 10.48 & 16.01 \\
\hline & Pic & Strip (38\%) & 300 & 114 & 677 & 28 & 51 & 56 & 975 & 2,129 & 4,726 & 1,870 & 2,727 & 16.40 & 23.92 \\
\hline & Pic & Strip (38\%) & 200 & 76 & 482 & 32 & 54 & 61 & 979 & 2,308 & 4,929 & 2,422 & 3,328 & 31.87 & 43.79 \\
\hline & $\begin{array}{l}\text { 1,3-D:Pic } \\
(63: 35)\end{array}$ & Strip (38\%) & 550 & 209 & 882 & 30 & 56 & 62 & 905 & 2,260 & 5,113 & 1,926 & 3,296 & 9.22 & 15.77 \\
\hline & $\begin{array}{l}\text { 1,3-D:Pic } \\
(39: 60)\end{array}$ & Strip (38\%) & 550 & 209 & 829 & 31 & 55 & 60 & 1,123 & 2,502 & 5,540 & 2,462 & 4,202 & 11.78 & 20.11 \\
\hline & $\begin{array}{l}\text { 1,3-D:Pic } \\
(39: 60)\end{array}$ & Strip (38\%) & 400 & 152 & 667 & 30 & 53 & 59 & 834 & 2,132 & 4,765 & 1,885 & 2,814 & 12.40 & 18.51 \\
\hline & IM:Pic (50:50) & Strip (38\%) & 400 & 152 & - & 30 & 57 & 62 & 948 & 2,120 & 5,107 & - & - & - & - \\
\hline & Pic & Spot (17\%) & 400 & 68 & 441 & 26 & 51 & 58 & 811 & 1,939 & 4,673 & 1,725 & 2,857 & 25.37 & 42.01 \\
\hline & $\begin{array}{l}\text { 1,3-D:Pic } \\
(63: 35)\end{array}$ & Spot (17\%) & 550 & 94 & 447 & 25 & 51 & 59 & 778 & 1,844 & 4,484 & 1,530 & 2,473 & 16.37 & 26.45 \\
\hline & $\begin{array}{l}\text { 1,3-D:Pic } \\
(63: 35)\end{array}$ & Full (100\%) & 550 & 550 & 2,169 & 31 & 55 & 61 & 941 & 2,285 & 5,364 & 688 & 2,511 & 1.25 & 4.57 \\
\hline & Value of $P$ : & & & & & $<0.0001$ & 0.002 & 0.24 & $<0.0001$ & $<0.0001$ & $<0.0001$ & & & & \\
\hline & $95 \%$ confiden & ce interval va & ues: & & & \pm 4 & \pm 4 & \pm 4 & \pm 240 & \pm 277 & \pm 473 & & & & \\
\hline \multirow[t]{14}{*}{ Madera } & Control & None & 0 & 0 & 0 & 25 & 30 & - & 274 & 973 & - & 0 & - & - & - \\
\hline & $\mathrm{MB}$ & Strip (45\%) & 400 & 180 & 1962 & 36 & 45 & - & 380 & 1,678 & - & (552) & - & $(3.07)$ & - \\
\hline & 1,3-D & Strip (38\%) & 340 & 129.2 & 393 & 35 & 42 & - & 405 & 1,496 & - & 653 & - & 5.05 & - \\
\hline & Pic & Strip (38\%) & 400 & 152 & 871 & 39 & 45 & - & 562 & 2,028 & - & 1,239 & - & 8.15 & - \\
\hline & Pic & Strip (38\%) & 300 & 114 & 677 & 40 & 47 & - & 516 & 1,930 & - & 1,237 & - & 10.85 & - \\
\hline & Pic & Strip (38\%) & 200 & 76 & 482 & 34 & 42 & - & 407 & 1,494 & - & 558 & - & 7.34 & - \\
\hline & $\begin{array}{l}\text { 1,3-D:Pic } \\
(63: 35)\end{array}$ & Strip (38\%) & 550 & 209 & 882 & 38 & 46 & - & 512 & 1,884 & - & 938 & - & 4.49 & - \\
\hline & $\begin{array}{l}\text { 1,3-D:Pic } \\
(39: 60)\end{array}$ & Strip (38\%) & 400 & 152 & 667 & 36 & 42 & - & 514 & 1,724 & - & 834 & - & 5.48 & - \\
\hline & IM:Pic (50:50) & Strip (38\%) & 400 & 152 & - & 43 & 51 & - & 517 & 2,185 & - & - & - & - & - \\
\hline & Pic & Spot (11\%) & 400 & 44 & 319 & 39 & 46 & - & 454 & 1,690 & - & 1,115 & - & 25.34 & - \\
\hline & $\begin{array}{l}\text { 1,3-D:Pic } \\
(63: 35)\end{array}$ & Spot (11\%) & 550 & 60.5 & 322 & 34 & 40 & - & 443 & 1,552 & - & 835 & - & 13.81 & - \\
\hline & $\begin{array}{l}\text { 1,3-D: Pic } \\
(63: 35)\end{array}$ & Full (100\%) & 550 & 550 & 2,169 & 42 & 50 & - & 485 & 2,300 & - & 483 & - & 0.88 & - \\
\hline & Value of $P$ : & & & & & 0.0003 & 0.0002 & & $<0.0001$ & $<0.0001$ & & & & & \\
\hline & $95 \%$ confiden & ce interval va & ues: & & & \pm 5 & \pm 6 & & \pm 64 & 433 & & & & & \\
\hline \multicolumn{16}{|c|}{$\begin{array}{l}\text { * Abbreviations indicate the following fumigants (and formulations): MB = methyl bromide 98\%, chloropicrin 2\% (MBC Concentrate, TriCal Inc.); 1,3-D = 1,3-dichloropropene } 98 \% \text { (Telone II, Dow AgroSciences); Pic } \\
=\text { chloropicrin } 99 \% \text { (Tri-Clor, TriCal Inc.); 1,3-D:Pic 63:35 = 1,3-dichloropropene 63\% + chloropicrin 35\% (Telone C35, Dow AgroSciences); 1,3-D:Pic 39:60 =1,3-dichloropropene 39\% + chloropicrin 60\% (Pic-Clor 60, } \\
\text { Dow AgroSciences); and IM:Pic = methyl iodide 50\%, chloropicrin 50\% (Midas, Arysta Life Sciences Inc.). } \\
\text { † Based on a net kernel price (i.e. the price after subtraction of nut hauling hulling and marketing costs of } \$ 2.00 \text { per lb.). }\end{array}$} \\
\hline
\end{tabular}


soil from one control plot, and no lesion, ring or root knot nematodes from other plots. In 2012 at Firebaugh, we detected no lesion, ring or root knot nematodes; at Madera, we detected 164 and 348 lesion nematodes per half pint (250 milliliters) in two respective control plots, and no lesion, ring or root knot nematodes in other plots. These results suggest that PRD was the dominant replant problem in these trials, but it is possible that plant parasitic nematode populations will build and have future economic impacts.

Despite the long-term uncertainties, our trials indicate that effective preplant soil fumigation can be an essential step in maximizing net revenues in replanted almond orchards, at least when 'Nemaguard' rootstock is used in the replanted orchard and PRD is active. Furthermore, our findings suggest that at orchard sites at risk for PRD and not infested with plant parasitic nematodes, growers can increase net revenues by using strip treatments with Pic or mixtures of Pic with 1,3-D instead of treatments with 1,3-D alone. Finally, the efficacies and efficiencies of GPS-controlled spot fumigation treatments indicate that they may have important applications where site or air quality sensitivities permit use of only very low rates of fumigant per acre.

\section{Microplot replant trials}

We conducted microplot trials to explore the potential of fallowing and crop rotation to remediate PRD. It was found in replanted apple orchards in Washington state that preplant rotation with wheat as a green manure lessened the severity of apple replant disease (Mazzola and Gu 2000; Mazzola and Mullinix 2005). Also, certain crops such as 'Piper' sudangrass have been recommended during fallow periods for suppression of nematode populations (Westerdahl et al. 2010). We investigated the potential for using shortterm crop rotation and fallowing to reduce the severity of PRD in California.

For this purpose, microplots were constructed at the San Joaquin Valley Agricultural Sciences Center (SJVASC), U.S. Department of AgricultureAgricultural Research Service (USDAARS), Parlier. The microplots consisted of sections of concrete pipe (24 inches in diameter by 48 inches long) inserted vertically into soil, with the rims protruding

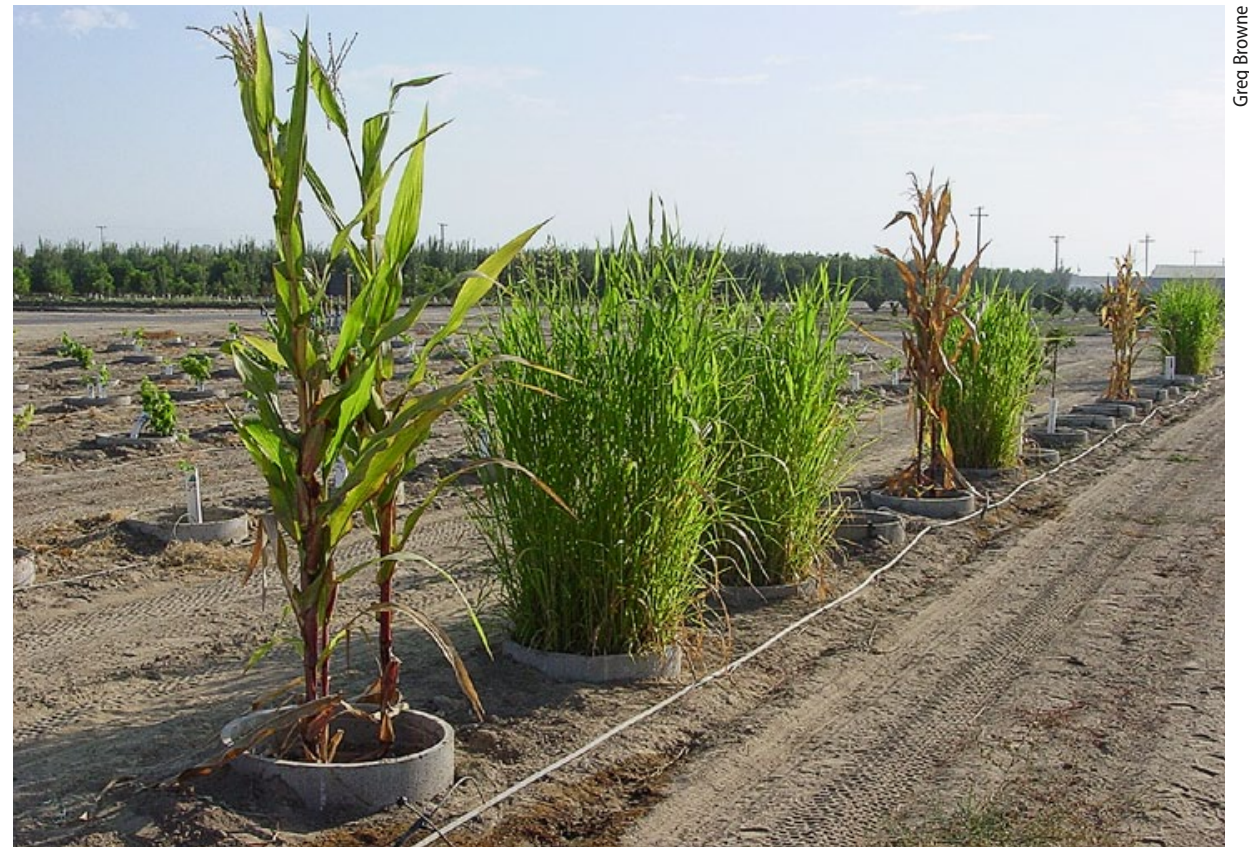

To test plant response to different soil treatments including preplant crop rotation, researchers established soil microplots by installing 4-foot lengths of 24-inch-diameter concrete pipe vertically into the soil and filling the pipes with soil from a nearby orchard affected with Prunus replant disease.

approximately 8 inches above the soil surface. The microplots were spaced 3 feet apart, edge to edge, and were filled with Hanford sandy loam soil that had been excavated from 0.3- to 2.5-foot depths in an adjacent peach orchard where trees had expressed PRD.

The soil in the microplots was planted with trees on 'Nemaguard' rootstock to maintain PRD induction potential, and the plants were watered with drip irrigation. Soil assays indicated that the soil did not have significant numbers of damaging plant parasitic nematodes.

Eight different treatments were imposed on the microplots in a randomized complete block design; there were five replicate microplots per treatment. The treatments were chosen to simulate remediation options of potential interest to almond and stone fruit growers during orchard replanting (table 2). For example, growers may choose to schedule orchard replacement to accommodate dry fallowing of the land for several months or years before replanting, or, alternatively, to replant quickly, without an extended fallow period. Also, whether or not fallowing is involved, growers typically have the option to fumigate the soil or leave it untreated before replanting. Fallowing and fumigation options were represented in treatments 1 to 4 (table 2). When an orchard-free period is observed before replanting, a rotation crop may be used. We selected treatments 5 to 8 to test some of the crop rotation options (table 2).

Treatment options 1 and 2 have the potential to be completed without losing a season of almond or peach production. Treatments 3 through 8 would typically require the loss of a crop cycle, unless a spring-harvested stone fruit variety was being replaced. If potted trees were to be used for the orchard replanting, it would be possible to complete the rotation with wheat alone (treatment 7) without loss of an almond or stone fruit cropping cycle (potted trees can be planted in late spring). Planting bareroot trees after the wheat rotation would require an undesirable delay. Unless kept in cold storage, bareroot trees are optimally planted by early February.

Details of the microplot trials were as follows: Three separate (repeat) experiments were completed. All three experiments had the same treatments, but the experiments were started successively, one year apart. In each experiment, the summer and fall portions of treatments 1 through 8 were imposed beginning in June of the year the experiment began (nearly 1 year before the microplots would be replanted with 'Nemaguard' peach plants.) The summer and fall portions of 
treatments 1 through 8 were continued until the following November, 4 months before replanting (table 2). During this period, the treatments involved maintaining growth of trees on 'Nemaguard' rootstock, dry fallowing (the soil was kept bare by hand-weeding) or growing hybrid corn or 'Piper' sudangrass (table 2). The 'Nemaguard,' corn and sudangrass plants were drip-irrigated to meet evapotranspiration needs, but the fallowed plots were not irrigated. All plots (including those fallowed) were fertilized periodically with equal amounts of ammonium sulfate fertilizer.

Near the end of the preplant period, in early November, the scions of trees on 'Nemaguard' rootstock (in treatments 1 and 2) and the tops of the sudangrass plants (treatments 6 and 8) were removed and then discarded outside the microplots. Also, the corn stalks (treatment 5) were chopped into pieces 2 to 3 inches long and kept within the microplots. The 'Nemaguard' and sudangrass root system residues and the corn roots and stubble were turned into the top foot of soil in their respective plots using a shovel to simulate thorough disking. Soil in all other plots was turned in the same manner, and the wheat was planted in its plots (treatments 7 and 8). In mid-November, the soil fumigation treatments were imposed on the appropriate plots using a microfumigation rig; MB plus Pic (50:50 formulation) was injected at 400 pounds per acre at 1 foot below the soil surface. At the end of the winter-spring period, soil in all plots, including those with wheat, was turned over repeatedly to a depth of 1 foot with a shovel to simulate disking.

In each of the three repeat experiments, we assessed efficacy of the preplant remediation treatments by replanting the microplots with 'Nemaguard' peach seedlings in the following March (i.e., for each experiment, nearly a year after the experiment's beginning) and measuring accumulated shoot weights of the seedlings the following November. The 'Nemaguard' seedlings were watered by drip irrigation to meet evapotranspiration demand and fertilized periodically with ammonium sulfate. All plots received the same irrigation and fertilization schedule, except in cases where soil moisture became excessive due to reduced water use by PRD-affected plants; in such cases, irrigation was briefly withheld from overly wet plots until soil moisture levels were similar among all plots.

\section{Microplot replant trial results}

In the three successive microplot trials (fig. 1, experiments 1, 2 and 3), several relatively consistent effects emerged, including the following:

- Preplant fumigation with MB plus Pic (50:50) consistently improved growth of replanted 'Nemaguard' peach seedlings, with or without extra preplant fallowing (fig. 1, treatments 1-4).

- The extra 5 months of preplant fallowing alone (fig. 1, treatment 3 ) did not significantly improve 'Nemaguard' growth, compared to the nonfallowed, nonfumigated control (treatment 1).

\begin{tabular}{|c|c|c|c|}
\hline \multirow[b]{2}{*}{$\begin{array}{c}\text { Treatment } \\
\text { number }\end{array}$} & \multicolumn{3}{|c|}{ Treatment sequence } \\
\hline & $\begin{array}{l}\text { Preplant cropping status in } \\
\text { summer/fall (Jun-Nov) }\end{array}$ & Fumigation treatment (Nov) & $\begin{array}{l}\text { Preplant cropping status in } \\
\text { winter/spring (Nov-Mar) }\end{array}$ \\
\hline 1 & 'Nemaguard' rootstock & None & Bare fallow \\
\hline 2 & 'Nemaguard' rootstock & $\mathrm{MB}+\mathrm{Pic}, 400 \mathrm{lb} / \mathrm{ac} \dagger$ & Bare fallow \\
\hline 3 & Bare fallow & None & Bare fallow \\
\hline 4 & Bare fallow & $\mathrm{MB}+\mathrm{Pic}, 400 \mathrm{lb} / \mathrm{ac}$ & Bare fallow \\
\hline 5 & Corn hybrid N8214* & None & Bare fallow \\
\hline 6 & 'Piper' sudangrass & None & Bare fallow \\
\hline 7 & Bare fallow & None & 'Penewawa' wheat $\neq$ \\
\hline 8 & 'Piper' sudangrass & None & 'Penewawa' wheat \\
\hline \multicolumn{4}{|c|}{$\begin{array}{l}\text { * Syngenta Seeds, NK Brand, Western Ag Services, Clovis, CA. } \\
\text { † Methyl bromide and Pic mixture (50:50, w:w). } \\
\text { ‡ Lake Seed Inc., Ronan, MT. }\end{array}$} \\
\hline
\end{tabular}

- A summer rotation with 'Piper' sudangrass (fig. 1, treatment 6) significantly improved growth of replanted 'Nemaguard,' as compared to fallowed and non-fallowed controls (treatments 1 and 3), but the degree of benefit did not consistently match that achieved by fumigation.

- Rotations involving corn or wheat (fig. 1 , treatments 5, 7 and 8) were sometimes beneficial, as compared to the controls (treatments 1 and 3).

These results suggest that some crop rotations, and particularly a summer rotation with 'Piper' sudangrass, may help

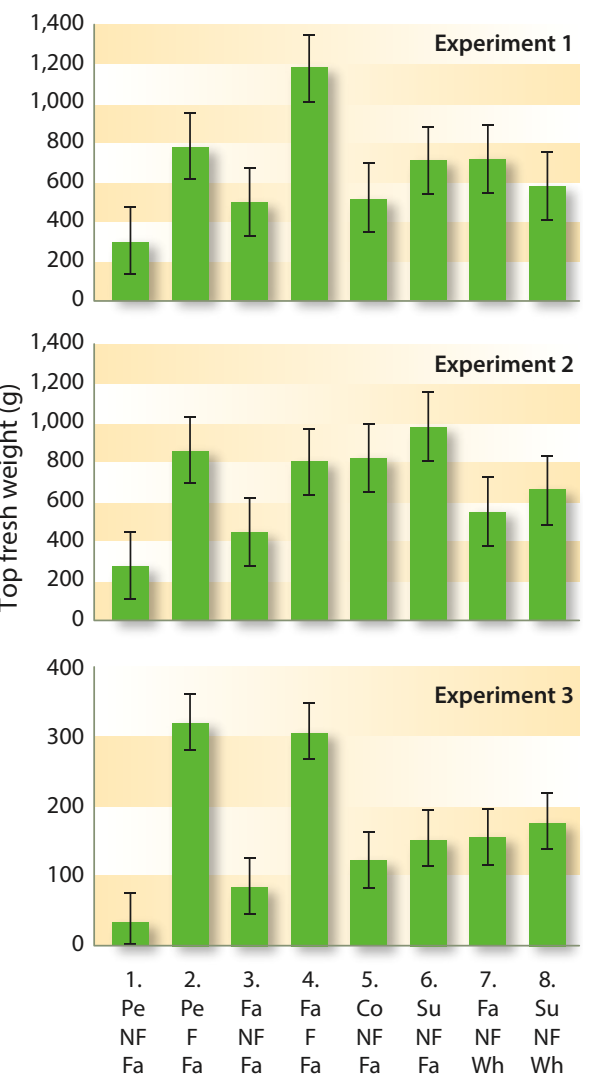

Fig. 1. Effects of preplant fallowing, crop rotation and fumigation on growth on 'Nemaguard' peach rootstock in microplot trials near Parlier. Experiments 1, 2 and 3 above were started in June of three successive years (2002, 2003 and 2004). For each experiment, treatment numbers are shown in the top row of $x$-axis labels; the second row of labels represents the corresponding cropping status of the treatments from June to November $(\mathrm{Pe}=$ peach, $\mathrm{Fa}=$ fallow, $\mathrm{Co}=$ corn, $\mathrm{Su}=$ sudangrass); the third row of labels indicates subsequent fumigation treatment $(\mathrm{NF}=$ nonfumigated, $\mathrm{F}=$ fumigated) and the fourth row of labels indicates subsequent cropping status from November to March ( $\mathrm{Fa}=$ fallow, $\mathrm{Wh}=$ wheat). Vertical bars are $95 \%$ confidence intervals. 
growers reduce the severity of PRD and thereby reduce the need for soil fumigation. Orchard validation of some of the microplot findings was completed in a peach replant trial, as described below.

\section{Peach replant trial}

Favorable responses to spot and strip fumigation treatments in the almond orchard replant trials and to crop rotation in the microplot trials led to validations in a peach orchard replant trial. For the experiment, plums on 'Nemaguard' rootstock were removed from a block at the SJVASC in early July 2007. The land was ripped to a depth of 2 to 3 feet, leveled, pre-irrigated and divided into five main plots, each of which was split in half. Each half of the five main plots measured 72 feet by 140 feet. One half was kept fallow (i.e., maintained relatively weed-free by a combination of cultivation and post-emergence herbicide treatments), while the other half was planted to 'Piper' sudangrass as a green manure crop. The sudangrass was grown for 2 months under sprinkler

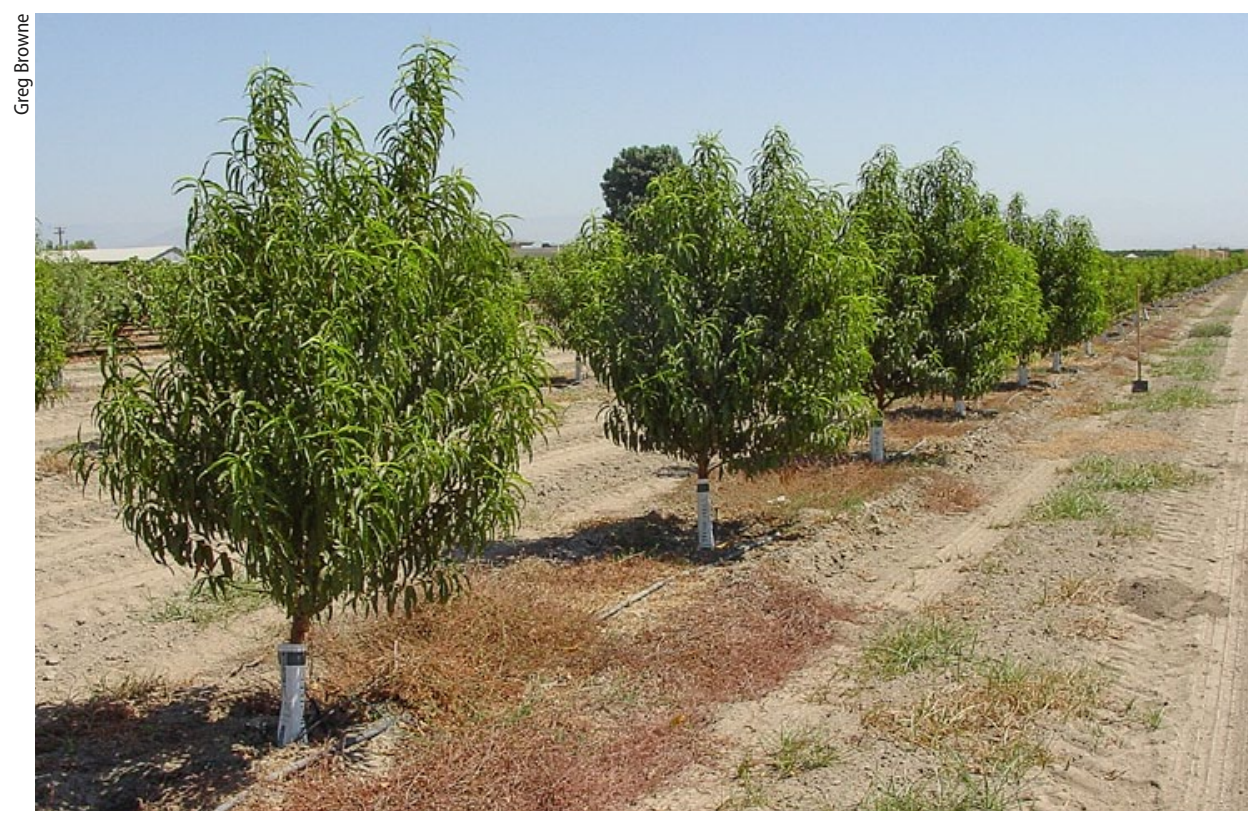

In the first growing season of the peach replant trial near Parlier, peach trees planted in preplant fumigated plots grew well (above, shown are trees in plot strip treated by shank injection of 1,3-D:Pic 63:35), while the peach trees planted into nonfumigated control plots grew poorly due to the PRD complex, below.

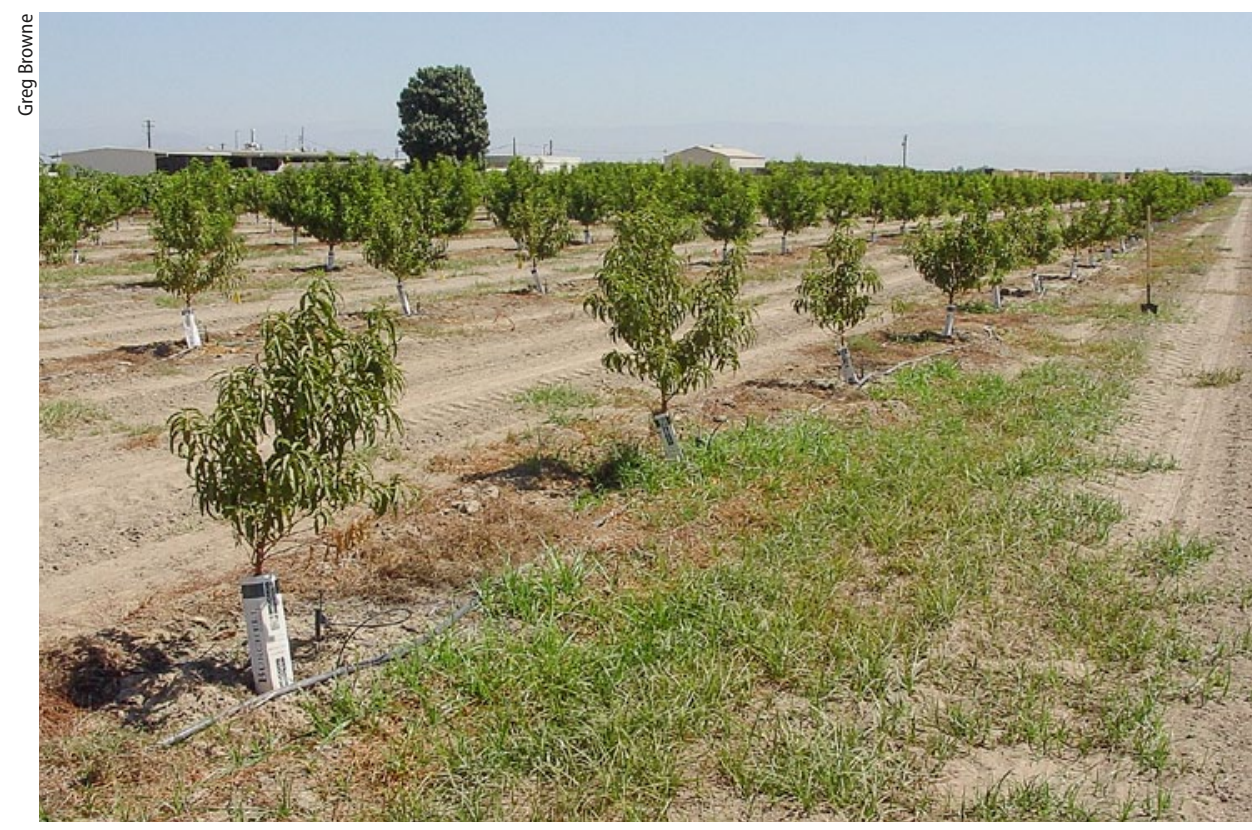

irrigation, then shredded and disked into the ground; the disking operation was extended across the whole field in preparation for preplant soil fumigation treatments.

Soil fumigation treatments were applied in late October 2007. The treatments were assigned randomly to 20 -foot-wide by 144-foot-long strip plots that ran across both halves of each main plot (i.e., the halves that had been cropped with sudangrass and those that were fallowed). Each of the fumigation treatment plots was centered over a single future tree row; the rows were to be spaced 20 feet apart.

The treatments included a nontreated control, a 10-foot-wide strip shank treatment with $\mathrm{MB}$, an 8.3-foot-wide strip treatment with 1,3-D:Pic 63:35, spot shank treatments with 1,3-D:Pic 63:35 and Pic (each applied to 5-foot by 6-foot areas centered on tree planting sites), and a drip-applied emulsified 1,3-D:Pic 61:35 (Inline, Dow Agrosciences) (applied to points centered under tree sites, as described below).

The shank treatments in the peach trial were applied in the same manner as in the almond replant trials, using the $\mathrm{MB}$ rig for the $\mathrm{MB}$ treatment and the Telone rig for the other shank treatments. As in the almond trials, the GPS software and hardware systems were used to map tree sites and administer the shank spot treatments. The drip spot treatment was applied through a single 1-gallon-perhour emitter per tree site; the emitter was connected to a tube that discharged the fumigant formulation 20 inches beneath the soil surface, as described previously (Wang et al. 2009).

In February 2008, all of the plots were planted with bareroot 'Burpeach 7' peach trees on 'Nemaguard' rootstock (Burchell Nursery, Oakdale, CA). Each replicate strip plot (i.e., the plots that received control and fumigation treatments) included 12 trees planted 12 feet apart in a row. Six of the 12 trees were in the half of the strip plot that had been planted to sudangrass, and six of the trees were in the half of the strip plot that had been fallowed. Efficacy of the treatments was assessed using methods described for the almond replant trials.

\section{Peach replant trial results}

Strong positive vegetative growth responses to all soil fumigation treatments 
were observed in the peach replant trial (e.g., photos, p 134) and led to profitable yield responses (table 3 ).

All preplant fumigation treatments greatly improved annual and cumulative yields, but the greatest yield increases were in the strip treatment with 1,3-D:Pic 63:35 (table 3). There were highly significant effects of preplant soil fumigation treatment on peach yields in each cropping year from 2009 through 2012 (data not shown) and for the cumulative yields across all 4 years (table $3, P<0.0001$ ).

The preplant rotation with sudangrass significantly improved annual peach yields in the second and fourth years of harvest $(P=0.03$ and 0.02 , respectively) and cumulative peach yields across all years $(P=0.03)$ (table 3$)$. There was no significant interaction between soil fumigation and crop rotation in annual or cumulative yields $(P>0.39)$.

Fruit size was affected by fumigation treatments in the first and third years of harvest $(P<0.0001$ and 0.003 , respectively) and in the cumulative yield $(P=0.05)$, but not in the second or fourth harvests $(P=0.08$ to 0.18$)$. In the cumulative yield, mean fruit weight for both the $\mathrm{MB}$ and 1,3-D:Pic 63:35 strip treatments was 0.39 pound per fruit $(95 \%$ confidence interval $[\mathrm{CI}] \pm 0.01$ pound), whereas fruit weight in all other preplant fumigation and control treatments was 0.37 pound per fruit $( \pm$ 0.01 pound). Preplant rotation with sudangrass improved fruit size only in 2009 $(P=0.007)$ and did not affect fruit size in the cumulative yields $(P=0.11)$. There was no significant interaction between soil fumigation and crop rotation that affected fruit size in annual or cumulative yields $(P>0.66)$.

Because stone fruit prices can vary greatly depending on time of harvest, changing markets, industrywide crop abundance and many other factors, economic value of the preplant treatments in the peach replant experiment was evaluated here assuming a range of net fruit prices (i.e., gross fruit returns minus harvest, packing, sales and marketing costs) of 24, 12, 6 and 3 cents per pound. Due to the relatively small effect of preplant treatments on fruit size in cumulative yields, fruit size effects on fruit price were not considered. Because there was no significant interaction between preplant
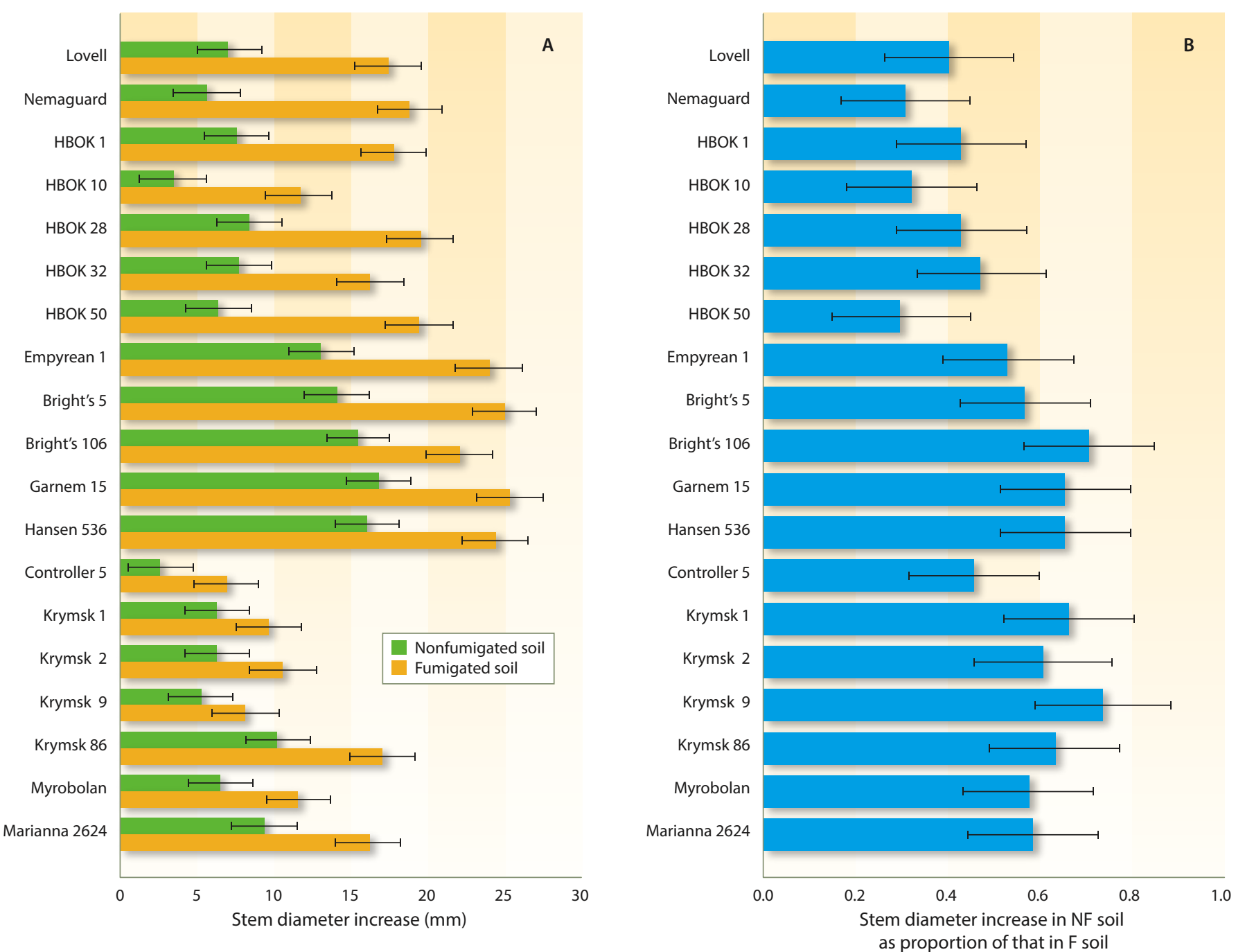

Fig. 2. Susceptibility of clonal almond and stone fruit rootstocks to Prunus replant disease complex. The rootstocks were transplanted into nonfumigated (NF) and fumigated (F) plots of soil. Stem diameter growth increases were measured from the time of planting in April 2011 to October 2011 . (A) Actual stem diameter increases, and (B) stem diameter increases in NF plots expressed as proportions of the increases in F plots (NF/F stem diameter increase proportions). There were eight replicate three-tree plots per treatment combination. Vertical bars are $95 \%$ confidence intervals. 
fumigation and crop rotation treatments, only the main treatment effects of the treatments were considered, unless stated otherwise.

Compared to the nonfumigated control, net returns were increased by all preplant fumigation treatments at all fruit return prices $(24,12,6$ and 3 cents per pound), except that at the lowest fruit price, MB fumigation reduced net returns (table 3). Increases in net revenues due to strip fumigation with 1,3-D:Pic 63:35 ranged from $\$ 13,465$ to $\$ 754$ per acre, depending on fruit pricing (table 3 ). The shank and drip spot treatments were less cost effective, generating returns that ranged from $\$ 8,958$ to $\$ 480$ per acre. Among the spot treatments, the shankapplied Pic resulted in the greatest net returns, followed by the spot treatments with 1,3-D:Pic via shank and drip (table 3). At a net fruit return price of 24 cents per pound, the cumulative net revenue increase due to spot treatment with Pic $(\$ 8,958)$ was similar to that associated with the MB treatment $(\$ 9,067$, table 3). At lower fruit prices all spot treatments remained economical, whereas the $\mathrm{MB}$ treatment became uneconomical.

In terms of efficiencies per pound of fumigant applied, the spot treatments held an advantage over the strip treatments. For example, increases in pounds of fruit yield per pound of $\mathrm{fu}$ migant applied were as follows: $\mathrm{MB}$ in shanked strips, 236; 1,3-D:Pic 63:35 in shanked strips, 262; 1,3-D:Pic 63:35 in shanked spots, 487; 1,3-D:Pic 61:33 in dripped spots, 832; and Pic in shanked spots, 785. Spot treatments also were more efficient than strip treatments in terms of dollars of net revenue increase generated per pound of fumigant; the increase in efficiency was apparent across the range of net fruit prices we considered ( 24 to 3 cents per pound of fruit) (table 3 ).

Since the effect of sudangrass rotation was statistically the same across all fumigation treatments (including the nonfumigated control), we first evaluated the returns that it generated on average, across the fumigation treatments (table 3). In this case, the sudangrass rotation increased net returns at all fruit prices considered, but as fruit price returns dropped from 24 to 3 cents per pound, the net return generated from the rotation dropped from $\$ 1,911$ per acre to $\$ 51$ per acre (table $3)$. When the sudangrass rotation was evaluated only in the context of the nonfumigated treatment, using only fruit yield data from those plots, the net return from sudangrass rotation ranged from $\$ 5,826$ at fruit return prices of 24 cents per pound to $\$ 541$ at fruit return prices of 3 cents per pound (data not shown).

Our peach orchard replant trial results documented the value of a sudangrass rotation in managing PRD over a broad range of fruit prices, even when the rotation was restricted to a 2-month period. Further work is needed, and justified, to optimize the use of sudangrass rotation; for example, a several-month rotation may have done more good, but this was not tested. The economic efficacy of the spot treatments in the peach trial, although not as great as in the comparable strip treatment, confirms almond replant trial results that indicated spot treatments may have a valuable niche where site sensitivity or grower preferences require the use of little fumigant.

\section{Evaluating rootstock resistance}

While seedling rootstocks are very important and useful in California almond and stone fruit production, new propagation technologies are facilitating improvement and use of clonal rootstocks. Several new, diverse clonal rootstocks have become available for almond and stone fruit production, but there is relatively little detailed information on their resistance to the PRD complex, an important consideration for growers wanting to use them for

TABLE 3. Results summary, peach replant trial near Parlier

\begin{tabular}{|c|c|c|c|c|c|c|c|c|c|c|c|}
\hline \multicolumn{2}{|c|}{ Treatment* } & & & \multirow{3}{*}{$\begin{array}{c}\begin{array}{c}\text { Cost of } \\
\text { treatment }\end{array} \\
\$ / a c r e\end{array}$} & \multirow{3}{*}{$\begin{array}{c}\begin{array}{c}\text { Cumulative } \\
\text { yield }\end{array} \\
\mathrm{lb} / \mathrm{acre}\end{array}$} & \multicolumn{4}{|c|}{$\begin{array}{c}\text { Net fruit prices and } \\
\text { net revenue gain } \dagger\end{array}$} & \multicolumn{2}{|c|}{$\begin{array}{l}\text { Net fruit price and } \\
\text { fumigant efficiency }\end{array}$} \\
\hline \multirow[t]{2}{*}{ Fumigant } & \multirow[t]{2}{*}{ Treated area } & \multicolumn{2}{|c|}{ Fumigant rate } & & & $\$ 0.24 / \mathrm{lb}$ & $\$ 0.12 / \mathrm{lb}$ & $\$ 0.06 / \mathrm{lb}$ & $\$ 0.03 / \mathrm{lb}$ & $\$ 0.24 / \mathrm{lb}$ & $\$ 0.03 / \mathrm{lb}$ \\
\hline & & $\mathrm{lb} /$ treated acre & Ib/orchard acre & & & $\ldots \ldots$ & $\cdots \cdots \$ / a$ & acre..... & $\ldots \ldots$ & net \$ gain & fumigant \\
\hline Control & None & 0 & 0 & 0 & 45,850 & 0 & 0 & 0 & 0 & - & - \\
\hline MB & Row strip (42\%) & 400 & 200 & 2,272 & 93,097 & 9,067 & 3,398 & 563 & (854) & 45.34 & $(4.27)$ \\
\hline 1,3-D:Pic (63:35) & Row strip (50\%) & 550 & 231 & 1,062 & 106,378 & 13,465 & 6,201 & 2,570 & 754 & 58.29 & 3.27 \\
\hline 1,3-D:Pic (63:35) & Tree spot (13\%) & 550 & 69 & 460 & 79,349 & 7,580 & 3,560 & 1,550 & 545 & 110.25 & 7.93 \\
\hline 1,3-D:Pic (61:33) & Tree spot (5\%) & 550 & 28 & 207 & 68,727 & 5,283 & 2,538 & 1,166 & 480 & 192.12 & 17.45 \\
\hline Pic & Tree spot (13\%) & 400 & 50 & 457 & 85,080 & 8,958 & 4,251 & 1,897 & 720 & 179.16 & 14.41 \\
\hline Value of $P$ : & & & & & $<0.0001$ & & & & & & \\
\hline $95 \%$ confidence & nterval values: & & & & $\pm 10,130$ & & & & & & \\
\hline No rotation with & udangrass & & & 0 & 75,320 & 0 & 0 & 0 & 0 & - & - \\
\hline Preplant rotation & with sudangrass & & & 214 & 84,174 & 1,911 & 849 & 317 & 51 & - & - \\
\hline Value of $P$ : & & & & & 0.03 & & & & & & \\
\hline $95 \%$ confidence & nterval values: & & & & $\pm 6,576$ & & & & & & \\
\hline
\end{tabular}


replanting of second- and later-generation orchards. Conceivably, rootstocks that resist or tolerate PRD could reduce or eliminate dependence on soil fumigation.

A field experiment was established at the SJVASC to evaluate resistance to PRD in 19 clonal almond, stone fruit and experimental rootstocks (table 4). The test site had been cleared from almonds on 'Nemaguard' rootstock in summer 2010. In October 2010, soil plots 350 feet long were shank-fumigated with 1,3-D:Pic 63:35 (540 lb/ac) or shanked without fumigant (control). There were eight replicate soil plots per soil treatment, arranged in randomized complete blocks. The soil treatment plots were subdivided into three-tree subplots that were randomly assigned to individual rootstocks.

The rootstocks were planted in April 2011 from pots. The trees were dripirrigated and fertilized periodically with urea ammonium nitrate. Resistance was assessed in October 2011 for each rootstock, block by block, by dividing rootstock stem diameter increase (measured from the time of planting) in the nonfumigated (NF) plot by the stem diameter increase in the fumigated (F) plot (i.e., the $\mathrm{NF} / \mathrm{F}$ stem diameter increase proportion). A repeat experiment was established in 2012 in an adjacent block using similar methods, except that the rootstocks were planted in May instead of April, and there were five replicate plots per soil treatment.

\section{Results of rootstock evaluations}

In the 2011 experiment, all rootstocks grew less in nonfumigated soil than in fumigated soil, but the severity of the growth reductions varied by rootstock (fig. 2A and 2B). The rootstock-soil treatment interaction was highly significant $(P$ $<0.0001)$. Most rootstocks with only peach parentage were relatively susceptible to the PRD complex in nonfumigated soil. For example, calculated NF/F stem diameter increase proportions for 'Harrow Blood' $\times$ 'Okinawa' clones (HBOK 1, 10, 28, 32 and 50), 'Lovell' and 'Nemaguard' peach ranged from 0.31 to 0.50 (fig. 2B). 'Empyrean 1,' also a peach, was the least susceptible of rootstocks with this parentage, with an NF/F stem diameter increase of 0.53 . The hybrid rootstocks that combined peach and almond parentage were less susceptible than most peaches; for example, 'Bright's Hybrid' clones 5 and 106, 'Garnem,' and 'Hansen 536' had NF/F

TABLE 4. Rootstocks included in 2011 and 2012 evaluations of resistance to Prunus replant disease complex

\begin{tabular}{|c|c|c|c|}
\hline Rootstock & Type* & Genetic background $\dagger$ & Compatible crops* \\
\hline 'HBOK1' & $\mathrm{Pe}$ & $H B \times O K$ peach & $\mathrm{Pe}$ \\
\hline 'HBOK 10' ('Controller 8') & $\mathrm{Pe}$ & $H B \times O K$ peach & $\mathrm{Pe}$ \\
\hline 'HBOK 28' & $\mathrm{Pe}$ & $H B \times O K$ peach & $\mathrm{Pe}$ \\
\hline 'HBOK 32' ('Controller 7') & $\mathrm{Pe}$ & $H B \times O K$ peach & $\mathrm{Pe}$ \\
\hline 'HBOK 50' ('Contoller 9.5') & $\mathrm{Pe}$ & $H B \times O K$ peach & $\mathrm{Pe}$ \\
\hline 'Lovell' & $\mathrm{Pe}$ & P. persica & $\mathrm{Al}, \mathrm{Pe}, \mathrm{Ap}, \mathrm{Pl}, \mathrm{Pr}$ \\
\hline 'Nemaguard' & $\mathrm{Pe}$ & P. persica $\times P$. davidiana & $\mathrm{Al}, \mathrm{Pe}, \mathrm{Ap}, \mathrm{PI}, \mathrm{Pr}$ \\
\hline 'Empyrean 1' ('Barrier 1') & $\mathrm{Pe}$ & P. persica $\times$ P. davidiana & $\mathrm{Pe}, \mathrm{Al}$ \\
\hline 'Bright's Hybrid 5' & $\mathrm{Pe} \times \mathrm{Al}$ & P. persica $\times$ P. dulcis & $\mathrm{Al}$ \\
\hline 'Bright's Hybrid 106' & $\mathrm{Pe} \times \mathrm{Al}$ & P. persica $\times P$. dulcis & $\mathrm{Al}$ \\
\hline 'GxN 15' ('Garnem') & $\mathrm{Pe} \times \mathrm{Al}$ & P. dulcis $\times$ P. persica ('Nemared') & $\mathrm{Al}$ \\
\hline 'Hansen 536' & $\mathrm{Pe} \times \mathrm{Al}$ & [Okin. $\times(P$. davidiana $\times$ 'Pe Pl 6582')] $\times$ alm. & $\mathrm{Al}, \mathrm{Ap}, \mathrm{Pe}$ \\
\hline 'Controller 5' (='K146-43') & PI hybrid & P. salicina $\times$ P. persica & $\mathrm{Pe}$ \\
\hline 'Krymsk 1' ('VVA 1') & PI hybrid & P. tomentosa $\times$ P. cerasifera & $\mathrm{Pl}$, some $\mathrm{Pe}$ \\
\hline 'Krymsk 2' & PI hybrid & P. incana $\times$ P. tomentosa & Unknown \\
\hline 'Krymsk 9' & PI hybrid & P. armeniaca $\times P$. ceracifera & Unknown \\
\hline 'Krymsk 86' ('Kuban 86') & PI hybrid & P. persica $\times P$. cerasifera & $\mathrm{Al}, \mathrm{Pe}, \mathrm{PI}$ \\
\hline 'Myrobalan' & PI hybrid & P. ceracifera & $\mathrm{Ap}, \mathrm{PI}, \mathrm{Pr}$ \\
\hline 'Marianna 2624' & PI hybrid & P. munsoniana $\times P$. cerasifera & $(\mathrm{Al}), \mathrm{Ap}, \mathrm{PI}, \mathrm{Pr}$ \\
\hline
\end{tabular}

stem diameter increase proportions of 0.57 to 0.71 . Rootstocks with plum parentage, including 'Controller 5,' 'Krymsk' clones 1, 2, 9 and 86, 'Marianna 2624,' and 'Myrobalan,' varied in susceptibility to the complex in nonfumigated soil (NF/F stem diameter increase proportions of 0.46 to 0.74 ).

Although some of the most vigorous rootstocks (e.g., the peach $\times$ almond hybrids and 'Empyrean 1') were also the least impacted by PRD, overall there was not a significant correlation between the magnitude of stem diameter increase values in fumigated plots (one measure of the inherent vigor of the rootstocks) and NF/F stem diameter increase proportions (our measure of PRD resistance) $(P=0.98)$. Also, genetic dissimilarity of the tested rootstocks with 'Nemaguard,' the rootstock used for the previous stone fruit orchard, was not a consistent predictor of the impact of PRD on rootstock growth. For example, 'Empyrean 1' (a peach, as is 'Nemaguard') was no more impacted by PRD than the rootstocks with plum parentage.

Evaluations of the rootstocks in the repeat (2012) trial are not complete but tend to confirm the results in the first (2011) trial. Overall, PRD severity in the repeat trial has been less than in the first trial, but NF/F stem diameter increase rankings were similar between the experiments. For example, in the repeat trial in September 2012, the rootstocks with peach parentage exhibited NF/F stem diameter increase proportions of 0.53 to 0.60, except for 'Empyrean 1,' which had an NF/F stem diameter increase proportion of 0.83 . The peach $\times$ almond hybrids were less suppressed than most peach rootstocks by the absence of fumigation (NF/F stem diameter increase proportions of 0.72 to 0.90$)$, and the rootstocks with plum parentage were variable (NF/F stem diameter increase proportions of 0.45 to 0.83 ).

As in the 2011 experiment, the rootstock-soil treatment interaction was significant in the 2012 experiment $(P=$ 0.0004). As in the first trial, in the repeat trial there has not been a significant overall correlation between the magnitude of stem diameter increase values in $\mathrm{fu}-$ migated plots (inherent vigor) and NF/F stem diameter increase proportions (PRD resistance) $(P=0.30)$, although some of 
the most vigorous rootstocks were among those most resistant to PRD.

The results of the rootstock trials suggest that judicious development and selection of rootstocks will contribute strongly to PRD management and reduce dependence on soil fumigation. Nevertheless, growers should carefully consider the horticultural suitability of prospective rootstocks to all of the demands of a site before choosing a rootstock. For example, due to their other susceptibilities, some peach $\times$ almond hybrid rootstocks are known as poor choices for replanting at sites subject to the ring nematode-bacterial canker complex or subject to poor drainage or problems with crown and root rot due to Phytophthora. UC farm advisors and fruit and nut nursery workers are valuable resources in rootstock selection.

\section{Meeting the replant challenge}

This report, although not exhaustive in scope, highlights the potential for integrated management of a key replant problem, PRD, with minimal dependence on soil fumigation. Optimized soil fumigation, crop rotation and careful rootstock selection all are valuable components for integrated management of PRD. Our almond and peach replant trials demonstrated that, when trees are at risk for PRD but not nematode damage, strip treatments with Pic or combinations of Pic and 1,3-D are likely to be more economical than strip treatments with 1,3-D alone, which is the current standard, or full-coverage treatments with 1,3-D:Pic 63:35. However, depending on the time of treatment, Pic application may require use of a tarp covering.

The trials also demonstrated the practical potential of GPS-controlled tree spot shank fumigation treatments, which made efficient use of limited amounts of fumigant to control PRD. Spot fumigation treatments may have great value for orchard replant sites where fumigant rates must be kept very low due to site regulatory restrictions. Microplot data suggested, and an orchard replant trial confirmed, that short-term rotations with 'Piper' sudangrass before orchard replanting can reduce subsequent PRD severity and thereby improve crop returns.

The sudangrass rotation improved net crop returns with or without preplant fumigation and across a wide range of profitable fruit prices, suggesting that the rotation is a prudent practice when it can be fit into stone fruit replanting schedules.

Finally, in a typical stone fruit replanting situation following removal of trees on 'Nemaguard' rootstock, we identified diverse replacement rootstocks (i.e., certain peach $\times$ almond, peach, and plum hybrid selections) with relatively low sensitivity to the resident PRD complex. In some situations, the rootstocks with reduced PRD sensitivity may markedly reduce the need for soil fumigation. Nevertheless, all site and scion cultivar factors should be considered carefully in choosing an orchard's rootstock(s). Continued selection and breeding of rootstocks will be essential in reducing dependence on soil fumigation.

G.T. Browne is Research Plant Pathologist, USDAARS and Department of Plant Pathology, UC Davis; B.D. Lampinen is UC Cooperative Extension Almond and Walnut Specialist, UC Davis; B.A. Holtz is UCCE County Director and Farm Advisor, San Joaquin County; D.A. Doll is UCCE Pomology Farm Advisor, Merced County; S.K. Upadhyaya

\section{References}

Bent E, Loffredo A, Yang JH, et al. 2009. Investigations into peach seedling stunting caused by a replant soil. FEMS Microbiol Ecol 68:192-200.

Browne GT, Connell JH, Schneider SM. 2006. Almond replant disease and its management with alternative preplant soil fumigation treatments and rootstocks. Plant Dis 90:869-76.

Cal-DPR. 2012. Volatile organic compound (VOC) emissions from pesticides. www.cdpr.ca.gov/docs/emon/ vocs/vocproj/vocmenu.htm.

Carpenter J, Lynch L, Trout T. 2001. Township limits on 1,3-D will impact adjustment to methyl bromide phase out. Calif Agr 55:12-8.

Coates R, Shafii M, Upadhaya S, Browne G. 2007. Tree planting site-specific fumigant application to control almond replant disease. In: Proc Ann Int Res Conf on Methyl Bromide Alternatives and Emissions Reductions, Oct. 29-Nov. 1, 2007. San Diego, CA. p 9-1, 9-2.

Lampinen BD, Udompetaikul V, Browne GT, et al. 2012. A mobile platform for measuring canopy photosynthetically active radiation interception in orchard systems. HortTechnology 22:237-44.

Larsen HJ. 1995. Replant disorders. In: Ogawa JM, Zehr El, Bird GW, et al. (eds.). Compendium of Stone Fruit Diseases. St. Paul: APS Press. p 46-7.

Mazzola M, Gu TH. 2000. Impact of wheat cultivation on microbial communities from replant soils and apple growth in greenhouse trials. Phytopathology 90:114-9. Mazzola M, Mullinix K. 2005. Comparative field efficacy of management strategies containing Brassica napus seed meal or green manure for the control of apple replant disease. Plant Dis 89:1207-13.

McKenry MV. 1996. Nematode parasites. In: Micke WC (ed.). Almond Production Manual. UC ANR Pub 3364. Oakland, CA. p 220-3. is Professor, Department of Biological and Agricultural Engineering, UC Davis; L.S. Schmidt is Biological Science Technician, USDA-ARS and Department of Plant Pathology, UC Davis; R.G. Bhat is Project Scientist, Department of Plant Pathology, UC Davis; V. Udompetaikul, former graduate student in the Department of Biological and Agricultural Engineering, UC Davis, is Professor, Department of Agricultural Engineering, King Mongkut's Institute of Technology, Ladkrabang, Thailand; R.W. Coates is Associate Development Engineer, Department of Biological and Agricultural Engineering, UC Davis; B.D. Hanson is UCCE Weed Specialist, Department of Plant Pathology, UC Davis; K.M. Klonsky is UCCE Specialist, Department of Agricultural and Resource Economics, UC Davis; S. Gao is Research Soil Scientist, USDA-ARS, Parlier; D. Wang is Research Leader, USDA-ARS, Parlier; M. Gillis is Research Associate, TriCal Inc., Hollister, California; J.S. Gerik is Research Plant Pathologist, USDA-ARS, Parlier; and R.S. Johnson is UCCE Specialist (retired), UC Kearney Agricultural Research and Extension Center.

The authors gratefully acknowledge support and assistance from the Pacific Area-Wide Pest Management Program, USDA-ARS, the Almond Board of California, the UC Agricultural Experiment Station, TriCal Inc., Paramount Farming, Agriland Farming, Bauer Farming, Harry Berberian and Sons, Donald Ewy, Mike Stanghellini, Burchell Nursery Inc., and Duarte Nursery Inc.

McKenry MV. 1999. The Replant Problem and Its Manage ment. Fresno, CA: Catalina Publishing.

McKenry MV. 2007. Development of nematode/rootstock profiles for 40 rootstocks with the potential to be an alternative to Nemaguard. In: Annual research report. Modesto, CA: Almond Board of California. p 1-13.

McKenry MV, Kretsch J. 1987. Survey of nematodes associated with almond production in California. Plant Dis 71:71-3.

Udompetaikul V, Coates RW, Upadhyaya SK, et al. In press. A tree-planting-site-specific fumigant applicator for orchard crops. Calif Agr 67.

Upadhyaya SK, Udompetaikul V, Shafii MS, Browne GT. 2009. Design, development and evaluation of a tree planting-site-specific fumigant applicator. Acta Hort 824:281-8.

USDA, NASS, California Field Office. 2011. Fruit and Nut Crops. California Agricultural Statistics, Crop Year 2010. www.nass.usda.gov/Statistics_by_State/California/Publications/California_Ag_Statistics/2010cas-frt.pdf. US EPA. 2012. The Phaseout of Methyl Bromide. www. epa.gov/ozone/mbr/.

Wang D, Browne G, Gao S, et al. 2009. Spot fumigation: Fumigant dispersion and emission characteristics. Environ Sci Technol 43:5783-9.

Westerdahl BB, McKenry MV. 2002. Diseases caused by nematodes. In: Teviotdale BL, Michailides TJ, Pscheidt JW (eds.). Compendium of Nut Crop Diseases in Temperate Zones. St. Paul: APS Press. p 11-4.

Westerdahl BB, McKenry MV, Duncan RA. 2010. UC Pest Management Guidelines, Peach: Nematodes. www.ipm. ucdavis.edu/PMG/r602200111.html. 